\title{
The impact of corporate governance measures on firm performance: the influences of managerial overconfidence
}

\author{
Tolossa Fufa Guluma* ${ }^{*}$
}

\begin{abstract}
The paper aims to investigate the impact of corporate governance (CG) measures on firm performance and the role of managerial behavior on the relationship of corporate governance mechanisms and firm performance using a Chinese listed firm. This study used CG mechanisms measures internal and external corporate governance, which is represented by independent board, dual board leadership, ownership concentration as measure of internal CG and debt financing and product market competition as an external CG measures. Managerial overconfidence was measured by the corporate earnings forecasts. Firm performance is measured by ROA and TQ. To address the study objective, the researcher used panel data of 11,634 samples of Chinese listed firms from 2010 to 2018. To analyze the proposed hypotheses, the study employed system Generalized Method of Moments estimation model. The study findings showed that ownership concentration and product market competition have a positive significant relationship with firm performance measured by ROA and TQ. Dual leadership has negative relationship with TQ, and debt financing also has a negative significant association's with both measures of firm performance ROA and TQ. Moreover, the empirical results also showed managerial overconfidence negatively influences the relationship of board independence, dual leadership, and ownership concentration with firm performance. However, managerial overconfidence positively moderates the impact of debt financing on firm performance measured by Tobin's $Q$ and negative influence on debt financing and operational firm performance relationship. These findings have several contributions: first, the study extends the literature on the relationship between CG and a firm's performance by using the Chinese CG structure. Second, this study provides evidence that how managerial behavioral bias interacts with CG mechanisms to affect firm performance, which has not been studied in previous literature. Therefore, the results of this study contribute to the theoretical perspective by providing an insight into the influencing role of managerial behavior in the relationship between CG practices and firm performance in an emerging markets economy. Hence, the empirical result of the study provides important managerial implications for the practice and is important for policy-makers seeking to improve corporate governance in the emerging market economy.
\end{abstract}

Keywords: Corporate governance, Firm performance, Managerial overconfidence, Emerging market

\section{Introduction}

Corporate governance and its relation with firm performance, keep on to be an essential area of empirical and theoretical study in corporate study. Corporate

*Correspondence: gulma19@yahoo.com

School of Business, University of International Business and Economics, Beijing 100029, China governance has got attention and developed as an important mechanism over the last decades. The fast growth of privatizations, the recent global financial crises, and financial institutions development have reinforced the improvement of corporate governance practices. Wellmanaged corporate governance mechanisms play an important role in improving corporate performance. Good corporate governance is fundamental for a firm 
in different ways; it improves company image, increases shareholders' confidence, and reduces the risk of fraudulent activities [67]. It is put together on a number of consistent mechanisms; internal control systems and external environments that contribute to the business corporations' increase successfully as a complete to bring about good corporate governance. The basic rationale of corporate governance is to increase the performance of firms by structuring and sustaining initiatives that motivate corporate insiders to maximize firm's operational and market efficiency, and long-term firm growth through limiting insiders' power that can abuse over corporate resources.

Several studies are contributed to the effect of CG on firm performance using different market developments. However, there is no consensus on the role CG on firm performance, due to different contextual factors. The role of CG mechanisms is affected by different factors. Prior studies provided different empirical evidence such as [14], suggested that the monitoring efficiency of the board of directors is affected by internal and external factors like government regulation and internal firm-specific factors; the role of board monitoring is determined by ownership structure and firm-specific characters Boone et al. [8], and Liu et al. [57] and Bozec [10] also reported that external market discipline affects the internal CG role on firm performance. Moreover, several studies studied the moderation role of different variables in between CG and firm value. Mcdonald et al. [63] studied CEO experience moderating the board monitoring effectiveness, and [60] studied the moderating role of product market competition in between internal CG and firm performance. Bozec [10] studied market disciple as a moderator between the board of directors and firm performance. As to the knowledge of the researcher, no study considered the influencing role of managerial overconfidence in between CG mechanisms and firm corporate performance. Thus, this study aims to investigate the influence of managerial overconfidence in the relationship between CG mechanisms and firm performance by using Chinese listed firms.

Managers (CEOs) were able to valuable contributions to the monitoring of strategic decision making [13]. Behavioral decision theory [94] suggests that overconfidence, as one type of cognitive bias, encourages decision-makers to overestimate their information and problem-solving capabilities and underestimates the uncertainties facing their firms and the potential losses from litigation associated with claims against them. Several prior studies reported different results of the manager's role in corporate governance in different ways. Previous studies claimed that overconfidence is a dysfunctional behavior of managers that deals with unfavorable consequences for the firm outcome, such as value distraction through unprofitable mergers and suboptimal investment behavior [61], and unlawful activities (Mishina et al. [64]). Oliver [68] argued the human character of individual managers affects the effectiveness of corporate governance. Top managers' behaviors and experience are primary determinants of directors' ability to effectively evaluate their managerial decision-making [45]. In another way, $[47,58]$ noted managerial overconfidence can encourage some risk and make up for managerial risk aversion, which leads to suboptimal investment decisions. Jensen [41] suggested in the presence of free cash flow, the manager may overinvest and they can accept a negative net present value project. Therefore, the existence of CG mechanisms aims to eliminate or reduce the effect of agency and asymmetric information on the CEO's decisions [62]. This means that the objectives of CG mechanisms are to counterbalance the effect of such problems in the corporate organization that may affect the value of the firms in the long run. Even with the absence of agency conflicts and asymmetric information problems, there is evidence documented for distortions such as the case of corporate investment. Managers will over- or under-invest regarding their optimism level and the availability of internal cash flow.

Agency theory by Jensen and Meckling [42] has a very clear vision of the problems that exist in the company to know the disagreement of interests between shareholders and managers. Irrational behavior of management resulting from behavioral biases of executive managers is a great challenge in corporate governance [44]. Overconfidence may create more agency conflict than normal managers. It may lead internal and external CG mechanisms to decisions which damage firm value. The role of CG mechanisms mitigating corporate governance results from agency costs, information asymmetry, and their impact on corporate decisions. This means the behavior of overconfident executives may affect controlling and monitoring role of internal/external CG mechanisms. According to Baccar et al. [5], suggestion is that one of the roles of corporate governance is controlling such managerial behavioral bias and limiting their potential effects on the company's strategies. These discussions lead to the conclusion that CEO overconfidence will negatively or positively influence the relationships of CG on firm performance. The majority of studies in the corporate governance field deal with internal problems associated with managerial opportunism, misalignment of objectives of managers and stakeholders. To deal with these problems, the firm may organize internal governance mechanisms, and in this section, the study provides a review of research focused on this specific aspect of corporate governance. 
Internal CG includes the controlling mechanism between various actors inside the firm: that is, the company management, its board, and shareholders. The shareholders delegate the controlling function to internal mechanisms such as the board or supervisory board. Effective internal CG is essential in accomplishing company strategic goals. Gillan [30] described internal mechanisms by dividing them into boards, managers, shareholders, debt holders, employees, suppliers, and customers. These internal mechanisms of CG work to check and balance the power of managers, shareholders, directors, and stakeholders. Accordingly, independent board, CEO duality, and ownership concentration are the main internal corporate governance controlling mechanisms suggested by various researchers in the literature. Thus, the study considered these three internal corporate structures in this study as internal control mechanisms that affect firm performance. Concurrently, external CG mechanisms are mechanisms that are not from the inside of the firm, which is from the outside of the firms and includes: market competition, take over provision, external audit, regulations, and debt finance. There are a lot of studies that examine and investigate the effect of external CG practices on the financial performance of a company, especially in developed nations. In this study, product market competition and debt financing have been taken as representatives of external CG mechanisms. Thus, the study used internal CG measures; independent board, dual leadership, ownership concentration, and productmarket competition, and debt financing as a proxy of external CG measures.

\section{Literature review and hypothesis building Corporate governance and firm performance}

Corporate governance has got attention and developed as a significant mechanism more than in the last decades. The recent financial crises, the fast growth of privatizations, and financial institutions have reinforced the improvement of corporate governance practices in numerous institutions of different countries. As many studies revealed, well-managed corporate governance mechanisms play an important role in providing corporate performance. Good corporate governance is fundamental for a firm in several ways: OECD [67] indicates the good corporate governance increases the company image, reduces the risks, and boosts shareholders' confidence. Furthermore, good corporate governance develops a number of consistent mechanisms, internal control systems and external environments that contribute to the business corporations' increase effectively as a whole to bring about good corporate governance.

The basic rationale of corporate governance is to increase the performance of companies by structuring and sustaining incentives that initiate corporate managers to maximize firm's operational efficiency, return on assets, and long-term firm growth through limiting managers' abuse of power over corporate resources.

Corporate governance mechanisms are divided into two broad categories: internal corporate governance and external corporate governance mechanisms. Supporting this concept, Keasey and Wright [43] indicated corporate governance as a framework for effective monitoring, regulation, and control of firms which permits alternative internal and external mechanisms for achieving the proposed company's objectives. The achievement of corporate governance relies on the mechanism effectiveness of both internal and external governance structures. Gillan [30] suggested that corporate governance can be divided into two: the internal and external mechanisms. Gillan [30] described internal mechanisms by dividing into boards, managers, shareholders, debt holders, employees, suppliers, and customers, and also explain external corporate governance mechanisms by incorporating the community in which companies operate, the social and political environment, laws and regulations that corporations and governments involved in.

The internal mechanisms are derived from ownership structure, board structure, and audit committee, and the external mechanisms are derived from the capital market corporate control market, labor market, state status, and investors activate [26]. The balance and effectiveness of the internal and external corporate governance practices can enhance a better corporate operational performance [21]. Literature argued that integrated and complete governance mechanisms are better with multi-dimensional theoretical view [87]. Thus, the study includes both internal and external CG mechanisms to broadly show the connection of these components. Filatotchev and Nakajima [26] suggest that an integrated approach bringing external and internal mechanisms jointly enhances to build up a more general view on the effectiveness and efficiency of different corporate governance mechanisms. Thus, the study includes both internal and external CG mechanisms to broadly show the connection of these three components.

Board of directors and ownership concentration are the main internal corporate governance mechanisms and product market competition and debt finance also the main representative of external corporate governance suggested by many researchers in the literature that were used in this study. Therefore, the following sections provide a brief discussion of internal and external corporate governance from different angles. 


\section{Independent board and firm performance}

Board of directors monitoring has been centrally important in corporate governance. Jensen [41] board of directors is described as the peak of the internal control system. The board represents a firm's owners and is responsible for ensuring that the firm is managed effectively. Thus, the board is responsible for adopting control mechanisms to ensure that management's behavior and actions are consistent with the interest of the owners. Mainly the responsibility of the board of directors is selection, evaluation, and removal of poorly performing CEO and top management, the determination of managerial incentives and monitoring, and assessment of firm performance [93]. The board of directors has the formal authority to endorse management initiatives, evaluate managerial performance, and allocate rewards and penalties to management on the basis of criteria that reflect shareholders' interests.

According to the agency theory board of directors, the divergence of interests between shareholders and managers is addressed by adopting a controlling role over managers. The board of directors is one of the key governance mechanisms; the board plays a pivotal role in monitoring managers to reduce the problems associated with the separation of ownership and management in corporations [24]. According to Chen et al. [16], the strategic role of the board became increasingly important and going beyond the mere approval of strategic management decisions. The board of directors must serve to reconcile management decisions with the objectives of shareholders and stakeholders, which can at times influence strategic decisions (Uribe-Bohorquez [85]). Therefore, the board's responsibilities extend beyond controlling and monitoring management, ensuring that it takes decisions that are reliable with the corporations [29]. In the perspective of resource dependence theory, an independent director is often linked firm to outside environments, who are non-management members of the board. Independent boards of directors are more believed to be effective in protecting shareholders' interests resulting in high performance [26]. This focus on board independence is grounded in agency theory, which addresses inefficiencies that arise from the separation of ownership and control [24]. As agency theory perspective boards of directors, particularly independent boards are put in place to monitor managers on behalf of shareholders [59].

A large number of empirical studies are undertaken to verify whether independent directors perform their governance functions effectively or not, but their results are still inconclusive. Studies [2, 50, 52, 56, 85], reported the supportive arguments that independent board of directors and firm performance have a positive relationship; in other ways, a large number of studies $[6,17,65$
91], and findings indicated the independent director has a negative relation with firm performance. The positive relationship of independent board and firm performance argued that firms which empower outside directors may lead to their more effective monitoring and therefore higher firm performance. The negative relationship of independent board and firm performance results are based on the argument that external directors have no access to information about the internal business of the firms and their relation with internal management does not allow them to have a sufficient understanding of the firm's day-to-day business activities or it may arise from the lack of knowledge of the business or the ability to monitor management actions [28].

Specifically in China, the corporate governance regulation code was approved in 2001 and required that the board of all Chinese listed domestic companies must include at least one-third of independent directors on their board by June 2003. Following this direction, many listed firms had appointed more independent directors, with a view to increase the independence of the board [54]. This proclamation is staying stable till now, and the number of independent directors in Chinese listed firms is increasing from time to time due to its importance. Thus, the following hypothesis is proposed.

Hypothesis 1 The proportion of independent directors in board members is positively related to firm performance.

\section{Dual leadership and firm performance}

CEO duality is one of the important board control mechanisms of internal CG mechanisms. It refers to a situation where the firm's chief executive officer serves as chairman of the board of directors, which means a person who holds both the positions of CEO and the chair. Regarding leadership and firm performance relation, there are different arguments; there is not consistent conclusion among different researchers. There are two competitive views about dual leadership in corporate governance literature. Agency theory view proposed that duality could minimize the board's effectiveness of its monitoring function, which leads to further agency problems and enhance poor performance $[41,83]$. As a result, dual leadership enhances CEO entrenchment and reduces board independence. In this condition, these two roles in one person made a concentration of power and responsibility, and this may result in busyness of CEO which affects the normal duties of a company. This means the $\mathrm{CEO}$ is responsible to execute a company's strategies, monitoring and evaluating the managerial activities of a company. Thus, separating these two roles is better to 
avoid concentration of authority and power in one individual and separate leadership of board from the ruling of the business [72].

On the other hand, stewardship theory suggests that managers are good stewards of company resources, which could benefit a firm [9]. This theory advocates that there is no conflict of interest between shareholders and managers, if the role of $\mathrm{CEO}$ and chairman vests on one person, rather CEO duality would promote a clear sense of strategic direction by unifying and strengthening leadership.

In the Chinese firm context, there are different conflicting conclusions about the relationship between CEO duality and firm performance.

Hypothesis 2 CEO duality is negatively associated with firm performance.

\section{Ownership concentration and firm performance}

The ownership structure is which has a profound effect on business strategy and performance. Agency theory [81] argued that concentrated ownership can monitor corporate operating management effectively, alleviate information problems and agency costs, consequently, improve firm performance. The concentration of ownership as a large number of studies grounded in agency theory suggests that it has both the incentive and influence to assure that managers and directors operate in the interests of shareholders [19]. Concentrated ownership presence among the firm's investors provides an important driver of good CG that should lead to efficiency gains and improvement in performance [81].

Due to shareholder concentrated economic risk, these shareholders have a strong encouragement to watch strictly over management, making sure that management does not engage in activities that are damaging the wealth of shareholders. Similarly, Shleifer and Vishny [80] argue that large share blocks reduce managerial opportunism, resulting in lower agency conflicts between management and shareholders.

In other ways, some researchers have indicated, block shareholders harmfully on the value of the firm, especially when majority shareholders can abuse their position of dominant control at the expense of minority shareholders [25]. As a result, at some level of ownership concentration the distinction between insiders and outsiders becomes unclear, and block-holders, no matter what their identity is, may have strong incentives to switch resources to the ways that make them better off at the cost of other shareholders. However, concentrated shareholding may create a new set of agency conflicts that may provide a negative impact on firm performance.
In the emerging market context, studies [77, 90] find a positive association between ownership concentration and accounting profit for Chinese public companies. As $\mathrm{Yu}$ and Wen [92] argued, Chinese companies have a concentrated ownership structure, limited disclosure, poor investor protection, and reliance on the banking system. As this study argues, this concentration is more controlled by the state, institution, and private shareholders. Thus, ownership concentration in Chinese firms may be an alternative governance tool to reduce agency problems and enhance efficiency.

Hypothesis 3 The ownership concentration is positively related to firm performance.

\section{Product market competition and firm performance}

Theoretical models have argued that competition in product markets is a powerful force for overcoming the agency problem between shareholders and managers [78]. Competition in product markets plays the role of a takeover [3], and well-managed firms take over the market from poorly managed firms. According to this study finding, competition helps to build the best management team. Competition acts as a substitute for internal governance mechanisms, practically the market for corporate control [3]. Chou et al. [18] provided evidence that product market competition has a substantial impact on corporate governance and that it substitutes for corporate governance quality, and they provide evidence that the disciplinary force of competition on the management of the firm is from the fear of insolvency. For instance, Ibrahim [39] reported firms to operate in competitive industries record more returns of share compared with the concentrated industries. Hart [33] stated that competition inspires managers to work harder and, thus, reduces managerial slack. This study suggests that in high competition, the selling prices of products or services are more likely to fall because managers are concerned with their economic interest, which may tie up with firm performance. Managers are more focused on enhancing productivity that is more likely to reduce cost and increase firm performance. Thus, competition in product market can reduce agency problems between owners and managers and can enhance performance.

Hypothesis 4 Product market competition is positively associated with firm performance.

\section{Debt financing and firm performance}

Debt financing is one of the important governance mechanisms in aligning the incentives of corporate managers with 
those of shareholders. According to agency theory, debt financing can increase the level of monitoring over selfserving managers and that can be used as an alternative corporate governance mechanism [40]. This theory argues two ways through debt finance can minimize the agency cost: first the potential positive impact of debt comes from the discipline imposed by the obligation to continually earn sufficient cash to meet the principal and interest payment. It is a commitment device for executives. Second leverage reduces free cash flows available for managers' discretionary expenses. Literature suggests that when leverage increases, managers may invest in high-risk projects in order to meet interest payments; this action leads lenders to monitor more closely the manager's action and decision to reduce the agency cost. Koke and Renneboog [48] have found empirical support that a positive impact of bank debt on productivity growth in German firms. Also, studies like $[77,86]$ examine empirically the effect of debt on firm investment decisions and firm value; reveal that debt finance is a negative effect on corporate investment and firm values [69] find that there is a significant and negative relationship between debt intensity and firm productivity in the case of Indian firms.

In the Chinese financial sectors, banks play a great role and use more commercial judgment and consideration in their leading decision, and even they monitor corporate activities [82]. In China listed company [77, 82] found that an increase in bank loans increases the size of managerial perks and free cash flows and decreases corporate efficiency, especially in state control firms. The main source of debts is state-owned banks for Chinese listed companies [82]. This shows debt financing can act as a governance mechanism in limiting managers' misuse of resources, thus reducing agency costs and enhance firm values. However, in China still government plays a great role in public listed company management, and most banks in China are also governed by the central government. However, the government is both a creditor and a debtor, especially in statecontrolled firms. Meanwhile, the government as the owner has multiple objectives such as social welfare and some national (political) issues. Therefore, when such an issue is considerable, debt financing may not properly play its governance role in Chinese listed firms.

Hypothesis 5 Debt financing has a negative association with firm performance

Influence of managerial overconfidence on the relationship of corporate governance and firm performance

Corporate governance mechanisms are assumed to be an appropriate solution to solve agency problems that may derive from the potential conflict of interest between managers and officers, on the one hand, and shareholders, on the other hand [42].

Overconfidence is an overestimation of one's own abilities and outcomes related to one's own personal situation [74]. This study proposed from the behavioral finance view that overconfidence is typical irrational behavior and that a corporate manager tends to show it when they make business decisions. Overconfident CEOs tend to think they have more accurate knowledge about future events than they have and that they are more likely to experience favorable future outcomes than they are [35]. Behavioral finance theory incorporates managerial psychological biases and emotions into their decision-making process. This approach assumes that managers are not fully rational. Concurrently, several reasons in the literature show managerial irrationality. This means that the observed distortions in CG decisions are not only the result of traditional factors. Even with the absence of agency conflicts and asymmetric information problems, there is evidence documented for distortions such as the case of corporate investment. Managers will over- or under-invest regarding their optimism level and the availability of internal cash flow. Such a result push managers to make sub-optimal decisions and increase observed corporate distortions as a result. The view of behavioral decision theory [94] suggests that overconfidence, as one type of cognitive bias, encourages decision-makers to overestimate their own information and problem-solving capabilities and underestimates the uncertainties facing their firms and the potential losses from proceedings related with maintains against them.

Researchers $[34,61]$ discussed the managerial behavioral bias has a great impact on firm corporate governance practices. These studies carefully analyzed and clarified that managerial overconfidence is a major source of corporate distortions and suggested good CG practices can mitigate such problems.

In line with the above argument and empirical evidence of several researchers, therefore, the current study tried to investigate how the managerial behavioral bias (overconfidence) positively or negatively influences the effect of CG on firm performance using Chinese listed firms.

The boards of directors as central internal CG mechanisms have the responsibility to monitor, control, and supervise the managerial activities of firms. Thus, the board of directors has the responsibility to monitor and initiate managers in the company to increase the wealth of ownership and firm value. The capability of the board composition and diversity may be important to control and monitor the internal managers' based on the nature of internal executives behaviors, managerial behavior bias that may hinder or smooth the progress of corporate decisions of the board of directors. 
Accordingly, several studies suggested different arguments; Delton et al. [20] argued managerial behavior is influencing the allocation of board attention to monitoring. According to this argument, board of directors or concentrated ownership is not activated all the time continuously, and board members do not keep up a constant level of attention to supervise CEOs. They execute their activities according to firm and CEO status. While the current performance of the firm desirable the success confers celebrity status on CEOs and board will be liable to trust the CEOs and became idle. In other ways, overconfidence managers are irrational behaviors that tend to consider themselves better than others on different attributes. They do not always form beliefs logically [73]. They blame the external advice and supervision, due to overestimating their skills and abilities, underestimate their risks [61]. Similarly, CEOs are the most decision-makers in the firm strategies. While managers are highly overconfident, board members (especially external) face information limitations on a day-to-day activities of internal managers. In other way, CEOs have a strong aspiration to increase the performance of their firm; however, if they achieve their goals, they may build their empire. This situation will pronounce where the market for corporate control is not matured enough like China [27]. So, this fact affects the effectiveness of board activities in strategic decision-making. In contrast, as the study [7] indicated, as the number of the internal board increases, the impact of managerial overconfidence in the firm became increasing and positively correlated with the leadership duality. In other ways, agency theory, many opponents suggest that $\mathrm{CEO}$ duality reduces the monitoring role of the board of directors over the executive manager, and this, in turn, may harm corporate performance. In line with this Khajavi and Dehghani, [44] found that as the number of internal board increases, the managerial overconfidence bias will increase in Tehran Stock Exchange during 2006-2012.

This shows us the controlling and supervising role of independent directors are less likely in the firms managed by overconfident managers than normal managers; conversely, the power of CEO duality is more salient in the case of overconfident managers than normal managers.

Hence:

Hypothesis 2a Managerial overconfidence negatively influences the relationship of independent board and firm performance.

Hypothesis 2b Managerial overconfidence strengthens the negative relationships of CEO duality and firm performance.
An internal control mechanism ownership concentration believes in the existence of strong control against the managers' decisions and choices. Ownership concentration can reduce managerial behaviors such as overconfidence and optimism since it contributes to the installation of a powerful control system [7]. They documented that managerial behavior affects the monitoring activities of ownership concentration on firm performance. Ownership can affect the managerial behavioral bias in different ways, for instance, when CEOs of the firm become overconfident for a certain time, the block ownership controlling attention is weakened [20], and owners trust the internal managers that may damage the performance of the firms in an emerging market where external market control is weak. Overconfidence CEOs have the quality that expresses their behavior up on their company [36]. In line with this fact, the researcher can predict that the impact of concentrated ownership on firm performance is affected by overconfident managers.

Hypothesis 2c Managerial overconfidence negatively influences the impact of ownership concentration on firm performance.

Theoretical literature has argued that product market competition forces management to improve firm performance and to make the best decisions for the future. In high competition, managers try their best due to fear of takeover [3], well-managed firms take over the market from poorly managed firms, and thus, competition helps to build the best management team. In the case of firms operating in the competitive industry, overconfidence CEO has advantages, due to its too simple to motivate overconfident managerial behaviors due to being overconfident managers assume his/her selves better than others. Overconfident CEOs are better at investing for future investments like research and development, so it plays a strategic role in the competition. Englmaier [23] argues firms in a more competitive industry better hire a manager who strongly believes in better future market outcomes.

Therefore, the following hypothesis was proposed:

Hypothesis 2d Managerial overconfidence moderates the effect of product market competition on firm performance.

Regarding debt financing, existing empirical evidence shows no specific pattern in the relation of managerial overconfidence and debt finance. Huang et al. [38] noted that overconfident managers normally overestimate the profitability of investment projects and underestimate the related risks. So, this study believes that firms 
with overconfident managers will have lower debt. Then, creditors refuse to provide debt finance when firms are facing high liquidity risks. Abdullah [1] also argues that debt financers may refuse to provide debt when a firm is having a low credit rating. Low credit rating occurs when bankers believe firms are overestimating the investment projects. Therefore, creditors may refuse to provide debt when managers are overconfident, due to under-estimating the related risk which provides a low credit rating.

However, in China, the main source of debt financers for companies is state banks [82], and most overconfidence CEOs in Chinese firms have political connections [96] with the state and have a better relationship with external financial institutions and public banks. Hence, overconfident managers have better in accessing debt rather than rational managers in the context of China that leads creditors to allow to follow and influence the firm investments through collecting information about the firm and supervise the firms directly or indirectly. Thus, managerial overconfidence could have a positive influence on relationships between debt finance and firm performance; thus, the following hypothesis is proposed:

Hypothesis 2e Managerial overconfidence moderates the relationship between debt financing and firm performance.

To explore the impact of CG on firm performance and whether managerial behavior (managerial overconfidence) influences the relationships of CG and firm performance, the following research model framework was developed based on theoretical suggestions and empirical evidence.

\section{Methods}

\section{Data sources and sample selection}

The data for this study required are accessible from different sources of secondary data, namely China Stock Market and Accounting Research (CSMAR) database and firm annual reports. The original data are obtained from the CSMAR, and the data are collected manually to supplement the missing value. CSMAR database is designed and developed by the China Accounting and Financial Research Center (CAFC) of Honk Kong Polytechnic University and by Shenzhen GTA Information Technology Limited company. All listed companies (Shanghai and Shenzhen stock Exchange) financial statements are included in this database from 1990 and 1991, respectively. All financial data, firm profile data, ownership structure, board structure, composition data of listed companies are included in the CSMAR database. The research employed nine consecutive years from 2010 to 2018 that met the condition that financial statements are available from the CSMAR database. This study sample was limited to only listed firms on the stock market, due to hard to access reliable financial and corporate governance data of unlisted firms. All data collected from Chinese listed firms only issued on A shares in domestic stoke market exchange of Shanghai and Shenzhen. The researcher also used only non-financial listed firms' because financial firms have special regulations. The study sample data were unbalanced panel data for nine consecutive years from 2010 to 2018. To match firms with industries, we require firms with non-missing CSRC top-level industry codes in the CSMAR database. After applying all the above criteria, the study's final observations are 11,634 firm-year observations.

\section{Measurement of variables Dependent variable}

Firm performance To measure firm performance, prior studies have been used different proxies, by classifying them into two groups: accounting-based and marketbased performance measures. Accordingly, this study measures firm performance in terms of accounting base (return on asset) and market-based measures (Tobin's Q). The ROA is measured as the ratio of net income or operating benefit before depreciation and provisions to total assets, while Tobin's $Q$ is measured as the sum of the market value of equity and book value of debt, divided by book value of assets.

\section{Independent Variables}

Board independent (BIND) Independent is calculated as the ratio of the number of independent directors divided by the total number of directors on boards. In the case of the Chinese Security Regulatory Commission (2002), independent directors are defined as the "directors who hold no position in the company other than the position of director, and no maintain relation with the listed company and its major shareholders that might prevent them from making objective judgment independently." In line with this definition, many previous studies used a proportion of independent directors to measure board independence $[56,79]$.

CEO Duality CEO duality refers to a position where the same person serves the role of chief executive officer of the form and as the chairperson of the board. CEO duality is a dummy variable, which equals 1 if the CEO is also the chairman of the board of directors, and 0 otherwise.

Ownership concentration (OWCON) The most common way to measure ownership concentration is in terms of the percentage of shareholdings held by shareholders. The percentage of shares is usually calculated as each share- 
holder's shareholdings held in the total outstanding shares of a company either by volume or by value in a stock exchange. Thus, the distribution of control power can be measured by calculating the ownership concentration indices, which are used to measure the degree of control or the power of influence in corporations [88]. These indices are calculated based on the percentages of a number of top shareholders' shareholdings in a company, usually the top ten or twenty shareholders. Following the previous studies [22], Wei Hu et al. [37], ownership concentration is measured through the total percentage of the 10 top block holders' ownership.

Product market competition (PMC) Previous studies measure it through different methods, such as market concentration, product substitutability and market size. Following the previous work in developed and emerging markets [product substitutability [31, 57], the current study measured using proxies of market concentration (Herfindahl-Hirschman Index (HHI)). The market share of every firm is calculated by dividing the firm's net sale by the total net sale of the industry, which is calculated for each industry separately every year. This index measures the degree of concentration by industry. The bigger this index is, the more the concentration and the less the competition in that industry will be, vice versa.

Debt Financing (DF) The debt financing proxy in this study is measured by the percentage of a total asset over the total debt of the firm following the past studies [69, 95].

\section{Interaction variable}

Managerial overconfidence (MOC) To measure MOC, several researchers attempt to use different proxies, for instance CEO's shareholdings [61] and [46]; mass media comments [11], corporate earnings forecast [36], executive compensation [38], and managers individual characteristics index [53]. Among these, the researcher decided to follow a study conducted in emerging markets [55] and used corporate earnings forecasts as a better indicator of managerial overconfidence. If a company's actual earnings are lower than the earnings expected by managers, the managers are defined as overconfident with a dummy variable of (1), and as not overconfident (0) otherwise.

\section{Control variables}

The study contains three control variables: firm size, firm age, and firm growth opportunities. Firm size is an important component while dealing with firm performance because larger firms have more agency issues and need strong CG. Many studies confirmed that a large firm has a large board of directors, which increases the monitoring costs and affects a firm's value (Choi et al., 2007). In other ways, large firms are easier to generate funds internally and to gain access to funds from an external source. Therefore, firm size affects the performance of firms. Firm size can be measured in many ways; common measures are market capitalization, revenue volume, number of employments, and size of total assets. In this study, firm size is measured by the logarithm of total assets following a previous study. Firm age is the number of years that a firm has operated; it was calculated from the time that the company first appeared on the Chinese exchange. It indicates how long a firm in the market and indicates firms with long age have long history accumulate experience and this may help them to incur better performance [8]. Firm age is a measure of a natural logarithm of the number of years listed from the time that company first listed on the Chinese exchange market. Growth opportunity is measured as the ratio of current year sales minus prior year sales divided by prior year sales. Sales growth enhances the capacity utilization rate, which spreads fixed costs over revenue resulting in higher profitability [49].

\section{Data analysis methods \\ Empirical model estimations}

Most of the previous corporate governance studies used OLS, FE, or RE estimation methods. However, these estimations are better when the explanatory variables are exogenous. Otherwise, a system generalized moment method (GMM) approach is more efficient and consistent. Arellano and Bond [4] suggested that system GMM is a better estimation method to address the problem of autocorrelation and unobservable fixed effect problems for the dynamic panel data. Therefore, to test the endogeneity issue in the model, the Durbin-Wu-Hausman test was applied. The result of the Hausman test indicated that the null hypothesis was rejected $(p=000)$, so there was an endogeneity problem among the study variables. Therefore, OLS and fixed effects approaches could not provide unbiased estimations, and the GMM model was utilized.

The system GMM is the econometric analysis of dynamic economic relationships in panel data, meaning the economic relationships in which variables adjust over time. Econometric analysis of dynamic panel data means that researchers observe many different individuals over time. A typical characteristic of such dynamic panel data is a large observation, small-time, i.e., that there are many observed individuals, but few observations over time. This is because the bias raised in the dynamic panel model could be small when time becomes large [75]. GMM is considered more appropriate to estimate panel data because it removes the contamination through an 
identified finite-sample corrected set of equations, which are robust to panel-specific autocorrelation and heteroscedasticity [12]. It is also a useful estimation tool to tackle the endogeneity and fixed-effect problems [4].

A dynamic panel data model is written as follows:

$$
\begin{aligned}
& \mathrm{y}_{\mathrm{it}}=\alpha \mathrm{y}_{\mathrm{it}-1}+\beta \mathrm{X}_{\mathrm{it}}+\varepsilon_{\mathrm{it}} \\
& \varepsilon_{\mathrm{it}}=\mu_{\mathrm{i}}+\mathrm{v}_{\mathrm{it}}
\end{aligned}
$$

where $y_{\text {it }}$ is the current year firm performance, $\alpha$ is representing the constant, $y_{\mathrm{it}-1}$ is the one-year lag performance, $i$ is the individual firms, and $t$ is periods. $\beta$ is a vector of independent variable. $X$ is the independent variable. The error terms contain two components, the fixed effect $\mu \mathrm{i}$ and idiosyncratic shocks $v_{\text {it }}$.

Accordingly, to test the impact of corporate governance mechanisms on firm performance and influencing role of the overconfident executive on the relationship between corporate governance mechanisms and firm performance, the following base models were used:

$\mathrm{ROA} / \mathrm{TQ}_{\mathrm{i}, t}=\alpha+\mathrm{yROA} / T Q_{i, t-1}+\beta_{1} \mathrm{INDBRD}+\beta_{2} \mathrm{D}$ $\mathrm{UAL}+\beta_{3} \mathrm{OWCON}+\beta_{4} \mathrm{DF}+\beta_{5} \mathrm{PMC}+\beta_{6} \mathrm{MOC}+$ $\beta_{7}$ FSIZE $+\beta_{8}$ FAGE $+\beta_{9}$ SGTH $+\beta_{10-14} \mathrm{MOC} *$ (INDBRD, DUAL, OWCON, DF, and PMC) + year dumm ies + industry Dummies $+\dot{\eta}+\varepsilon_{i t}$.

where $i$ and $t$ represent firm $i$ at time $t$, respectively, $\alpha$ represents the constant, and $\beta_{1-9}$ is the slope of the independent and control variables which reflects a partial or prediction for the value of dependent variable, $\eta$ represents the unobserved time-invariant firm effects, and $\varepsilon_{\text {it }}$ is a random error term.

\section{Results}

\section{Descriptive statistics}

Descriptive statistics of all variables included in the model are described in Table 1. Accordingly, the value of ROA ranges from -0.17 to 0.23 , and the average value of ROA of the sample is 0.05 (5.4\%). Tobin Q's value ranges from 0.88 to 10.06 , with an average value of 2.62 . The ratio of the independent board ranges from 0.33 to 0.57 . The average value of the independent board of directors' ratio was 0.374 . The proportion of the CEO serving as chairperson of the board is 0.292 or $29.23 \%$ over the nine years. Top 10 ownership concentration of the study ranged from $22.59 \%$ to $90.3 \%$, and the mean value is $58.71 \%$. Product market competition ranges from $0.85 \%$ to $40.5 \%$, with a mean value of $5.63 \%$. The debt financing also has a mean value of $40.5 \%$, with a minimum value of $4.90 \%$ and a maximum value of $87 \%$. The mean value of managerial overconfidence is 0.589 , which indicates more than $50 \%$ of Chinese top managers are overconfident.

The study sample has an average of 22.15 million RMB in total book assets with the smallest firms asset 20 million RMB and the biggest owned 26 million RMB. Study sample average firms' age was 8.61 years old. The growth opportunities of sample firms have an average value of $9.8 \%$.

Table 2 presents the correlation matrix among variables in the regression analysis in the study. As a basic check for multicollinearity, a correlation of 0.7 or higher in absolute value may indicate a multicollinearity issue [32]. According to Table 2 results, there is no multicollinearity problem among variables. Additionally, the variance inflation factor (VIF) test also shows all explanatory

\begin{tabular}{|c|c|c|c|c|c|}
\hline Variable & $N=11,634$ & Mean & Std. Dev & Min & Max \\
\hline \multicolumn{6}{|c|}{ Dependent variables (Firm performance) } \\
\hline Return on Asset & & .057744 & .0533432 & -.1735858 & .2275309 \\
\hline Tobin's Q & & 2.739432 & 1.772316 & .884476 & 10.06002 \\
\hline \multicolumn{6}{|l|}{ Independent (CG) variables } \\
\hline Independent board & & .3739679 & .0535505 & .3333333 & .5714286 \\
\hline Dual leadership & & .2897542 & .4536677 & 0 & 1 \\
\hline Ownership concentration & & 58.54636 & 14.9478 & 22.5897 & 90.2627 \\
\hline Product market concentration & & .0580452 & .092206 & .0084798 & .4052926 \\
\hline Debt financing & & .3986051 & .2017631 & .0488051 & .8691791 \\
\hline \multicolumn{6}{|l|}{ Interaction variable } \\
\hline Managerial overconfidence & & .5893932 & .4919651 & 0 & 1 \\
\hline \multicolumn{6}{|l|}{ Control variables } \\
\hline Firm size & & 22.04965 & 1.217836 & 19.92883 & 25.97107 \\
\hline Firm age & & 8.864106 & 5.7934684 & 2.079442 & 27.526361 \\
\hline Growth opportunity & & .098404 & .2327094 & -.8339386 & .7059863 \\
\hline
\end{tabular}

Table 1 Descriptive statistics 
variables are below the threshold value of 10, [32] which indicates that no multicollinearity issue exists.

\section{Main results and discussion Impact of CG on firm performance}

Accordingly, Tables 3 and 4 indicate the results of twostep system GMM employing the xtabond2 command introduced by Roodman [75]. In this, the two-step system GMM results indicated the CG and performance relationship, with the interaction of managerial overconfidence. One-year lag of performance has been included in the model and two to three periods lagged independent variables were used as an instrument in the dynamic model, to correct for simultaneity, control for the fixed effect, and to tackle the endogeneity problem of independent variables. In this model, all variables are taken as endogenous except control variables.

Tables 3 and 4 report the results of three model specification tests to determine whether an appropriate estimation model was applied. These tests are: 1) the Arellano-Bond test for the first-order (AR (1)) and second-order correlation (AR (2)). This test indicates the result of AR (1) and AR (2) is tested for the first-order and second-order serial correlation in the first-differenced residuals, AR (2) test accepted under the null of no serial correlation. The model results show AR (2) test yields a p-value of 0.511 and 0.334 , respectively, for ROA and TQ firm performance measurement, which indicates that the models cannot reject the null hypothesis of no secondorder serial correlation. 2) Hansen test over-identification is to detect the validity of the instrument in the models. The Hansen test of over-identification is accepted under the null that all instruments are valid. Tables 3 and 4 indicate the p-value of Hansen test over-identification 0.139 and 0.132 for ROA and TQ measurement of firm performance, respectively, so that these models cannot reject the hypothesis of the validity of instruments. 3) In the difference-in-Hansen test of exogeneity, it is acceptable under the null that instruments used for the equations in levels are exogenous. Table 3 shows p-values of 0.313 and 0.151 , respectively, for ROA and TQ. These two models cannot reject the hypothesis that the equations in levels are exogenous.

Tables 3 and 4 report the results of the one-year lag values of ROA and TQ are positive $(0.398,0.658)$ and significant at less than $1 \%$ level. This indicates that the previous year's performance of a Chinese firm has a significant impact on the current firm's performance. This study finding is consistent with the previous studies: Shao [79], Nguyen [66] and Wintoki et al. [89], which considered previous year performance as one of the significant independent variables in the case of corporate governance mechanisms and firm performance relationships.

The results indicate board independence has no relation with firm performance measured by ROA and TQ. However, hypothesis 1 indicated that there is a positive and significant relationship between independent board and firm performance, which is not supported. The results are conflicting with the assumption that high independent board on board room should better supervise managers, alleviate the information asymmetry between agents and owners, and improve the firm performance by their proficiency. This result is consistent with several previous studies $[56,79]$, which confirms no relation between board independence and firm performance.

This result is consistent with the argument that those outside directors are inefficient because of the lack of enough information concerning the daily activities of internal managers. Specifically, Chinese listed companies may simply include the minimum number of independent directors on board to fulfill the institutional requirement and that independent boards are only obligatory and fail to perform their responsibilities [56, 79]. In this study sample, the average of independent board of all firms included in this study has only 37 percent, and this is one of concurrent evidence as to the independent

Table 2 Correlation matrix and VIF of variables

\begin{tabular}{|c|c|c|c|c|c|c|c|c|c|c|}
\hline Variables & 1 & 2 & 3 & 4 & 5 & 6 & 7 & 8 & 9 & VIF \\
\hline Ownership concentration & 1 & & & & & & & & & 1.07 \\
\hline Board independence & $.052^{* * *}$ & 1 & & & & & & & & 1.02 \\
\hline Dual leadership & $.053^{* * *}$ & $.121^{* * *}$ & 1 & & & & & & & 1.06 \\
\hline Debt finance & $-.126^{* * *}$ & $-.014^{*}$ & $-.145^{* * *}$ & 1 & & & & & & 1.49 \\
\hline Product market competition & $.032^{* * *}$ & $.039^{* * *}$ & -.004 & $-.033^{* * *}$ & 1 & & & & & 1.00 \\
\hline Managerial overconfidence & $-.067^{* * *}$ & -.009 & $-.081^{* * *}$ & $.151^{* * *}$ & $.025^{* * *}$ & 1 & & & & 1.05 \\
\hline Firm size & $.081^{* * *}$ & .006 & $-.178^{* * *}$ & $.543^{* * *}$ & -.008 & $.175^{* * *}$ & 1 & & & 1.51 \\
\hline Firm age & $-.232^{* * *}$ & $-.056^{* * *}$ & $-.089^{* * *}$ & $.165^{* * *}$ & $-.089^{* * *}$ & $.049^{* * *}$ & $.182^{* * *}$ & 1 & & 1.12 \\
\hline Growth opportunity & $.109^{* * *}$ & -.012 & $.049^{* * *}$ & $-.024^{* * *}$ & .013 & $-.094^{* * *}$ & $.033^{* * *}$ & $-.049^{* * *}$ & 1 & 1.02 \\
\hline
\end{tabular}


Table 3 Regression results of influences of managerial overconfidence in the relationship of corporate governance mechanisms and firm performance $(\mathrm{ROA})$

\begin{tabular}{|c|c|c|c|c|c|c|c|}
\hline \multirow[t]{2}{*}{ Variables } & \multicolumn{7}{|c|}{ Firm performance (ROA) } \\
\hline & (1) & $(2)$ & (3) & (4) & (5) & (6) & (7) \\
\hline \multirow[t]{2}{*}{ L.ROA } & $0.398^{* * *}$ & $0.401^{* * *}$ & $0.403^{* * *}$ & $0.399^{* * *}$ & $0.399^{* * *}$ & $0.405^{* * *}$ & $0.401^{* * *}$ \\
\hline & $(0.0251)$ & $(0.0251)$ & $(0.0253)$ & $(0.0255)$ & $(0.0252)$ & $(0.0247)$ & $(0.0251)$ \\
\hline \multirow[t]{2}{*}{ BIND } & 0.0823 & $0.0900^{*}$ & 0.113 & $0.0899^{*}$ & 0.0861 & $0.0897^{*}$ & $0.0899^{*}$ \\
\hline & $(0.0539)$ & $(0.0542)$ & $(0.0978)$ & $(0.0543)$ & $(0.0541)$ & $(0.0538)$ & $(0.0542)$ \\
\hline \multirow[t]{2}{*}{ DUAL } & $0.0103^{* *}$ & $0.00987^{* *}$ & $0.00931^{*}$ & $0.0200^{* *}$ & $0.00910^{*}$ & $0.00973^{* *}$ & $0.00987^{* *}$ \\
\hline & $(0.00484)$ & $(0.00481)$ & $(0.00482)$ & $(0.00925)$ & $(0.00485)$ & $(0.00480)$ & $(0.00482)$ \\
\hline \multirow[t]{2}{*}{ OWCON } & $0.000462^{* * *}$ & $0.000499^{* * *}$ & $0.000506^{* * *}$ & $0.000501^{* * *}$ & $0.000745^{* * *}$ & $0.000497^{* * *}$ & $0.000499 * * *$ \\
\hline & $(0.000108)$ & $(0.000107)$ & $(0.000106)$ & $(0.000108)$ & $(0.000192)$ & $(0.000107)$ & $(0.000107)$ \\
\hline \multirow[t]{2}{*}{ DF } & $-0.0594^{* * *}$ & $-0.0578^{* * *}$ & $-0.0570^{* * *}$ & $-0.0577^{* * *}$ & $-0.0581^{* * *}$ & -0.0290 & $-0.0579^{* * *}$ \\
\hline & $(0.0126)$ & $(0.0126)$ & $(0.0126)$ & $(0.0127)$ & $(0.0126)$ & $(0.0216)$ & $(0.0126)$ \\
\hline \multirow[t]{2}{*}{ PMC } & 0.0174 & 0.0186 & 0.0185 & 0.0211 & 0.0190 & 0.0194 & 0.0180 \\
\hline & $(0.0175)$ & $(0.0174)$ & $(0.0175)$ & $(0.0174)$ & $(0.0174)$ & $(0.0174)$ & $(0.0194)$ \\
\hline \multirow[t]{2}{*}{ MOC } & & $-0.00832^{* * *}$ & 0.0366 & -0.00234 & 0.0148 & 0.00986 & $-0.00836^{* * *}$ \\
\hline & & $(0.000926)$ & $(0.0334)$ & $(0.00275)$ & $(0.00990)$ & $(0.00653)$ & $(0.00109)$ \\
\hline \multirow[t]{2}{*}{ FSIZE } & $0.00475^{* * *}$ & $0.00511^{* * *}$ & $0.00503^{* * *}$ & $0.00491^{* * *}$ & $0.00527^{* * *}$ & $0.00495^{* * *}$ & $0.00511^{* * *}$ \\
\hline & $(0.00120)$ & $(0.00120)$ & $(0.00119)$ & $(0.00120)$ & $(0.00120)$ & $(0.00121)$ & $(0.00120)$ \\
\hline \multirow[t]{2}{*}{ FAGE } & $0.0133^{* * *}$ & $0.0148^{* * *}$ & $0.0135^{* * *}$ & $0.0146^{* * *}$ & $0.0143^{* * *}$ & $0.0144^{* * *}$ & $0.0148^{* * *}$ \\
\hline & $(0.00257)$ & $(0.00256)$ & $(0.00242)$ & $(0.00257)$ & $(0.00245)$ & $(0.00259)$ & $(0.00255)$ \\
\hline \multirow[t]{2}{*}{ SGWTH } & $0.0655^{* * *}$ & $0.0637^{* * *}$ & $0.0638^{* * *}$ & $0.0635^{* * *}$ & $0.0636^{* * *}$ & $0.0634^{* * *}$ & $0.0638^{* * *}$ \\
\hline & $(0.00275)$ & $(0.00275)$ & $(0.00275)$ & $(0.00276)$ & $(0.00275)$ & $(0.00275)$ & $(0.00275)$ \\
\hline \multirow[t]{2}{*}{ Moc*BIND } & & & -0.120 & & & & \\
\hline & & & $(0.0887)$ & & & & \\
\hline \multirow[t]{2}{*}{ Moc*DUAL } & & & & $-0.0202^{* *}$ & & & \\
\hline & & & & $(0.00838)$ & & & \\
\hline \multirow[t]{2}{*}{ Moc*OWCON } & & & & & $-0.000404^{* *}$ & & \\
\hline & & & & & $(0.000170)$ & & \\
\hline \multirow[t]{2}{*}{ Moc*DF } & & & & & & $-0.0449^{* * *}$ & \\
\hline & & & & & & $(0.0162)$ & \\
\hline \multirow[t]{2}{*}{ Moc*PMC } & & & & & & & 0.000640 \\
\hline & & & & & & & $(0.0111)$ \\
\hline \multirow[t]{2}{*}{ Constant } & 0 & 0 & $-0.197^{* * *}$ & 0 & 0 & $-0.200^{* * *}$ & 0 \\
\hline & (0) & (0) & $(0.0459)$ & (0) & (0) & $(0.0334)$ & (0) \\
\hline Industries/year dummies & Yes & Yes & Yes & Yes & Yes & Yes & Yes \\
\hline Observations & 11,634 & 11,634 & 11,634 & 11,634 & 11,634 & 11,634 & 11,634 \\
\hline Number of firms & 2,492 & 2,492 & 2,492 & 2,492 & 2,492 & 2,492 & 2,492 \\
\hline AR(1) test ( $p$-value) & 0.000 & 0.000 & 0.000 & 0.000 & 0.000 & 0.001 & 0.000 \\
\hline AR(2) test ( $p$-value) & 0.511 & 0.500 & 0.492 & 0.499 & 0.580 & 0.452 & 0.505 \\
\hline Hansen test of over identification & 0.139 & 0.108 & 0.178 & 0.176 & 0.121 & 0.160 & 0.114 \\
\hline Difference test of exogenous & 0.313 & 0.223 & 0.296 & 0.247 & 0.359 & 0.226 & 0.218 \\
\hline
\end{tabular}

${ }^{*}, * *{ }^{* * *}$ represent the statistical significance at $1 \%, 5 \%$, and $10 \%$ level, respectively

Notes This table reports the system GMM regression results to capture the relationship of CG and firm performance, and interaction effect of MOC and CG on firm performance. Variables included in this model: dependent variable measured by return on asset (ROA); independent variables are: independent board (BIND), dual leadership (DUAL), ownership concentration (OWCON), debt financing (DF), and product market competition (PMC). The interaction variable is managerial overconfidence (MOC). Control variables include firm size (FSIZE), firm age (FAGE), and growth opportunities (SGWTH). The system GMM estimate under column 1 indicates the relationship between CG and firm performance. Column 2 indicates the effect of CG and MOC on firm performance (ROA), and columns 3-7 indicated the influence of interaction terms (MOC ${ }^{*} \mathrm{CG}$ ) one by one on ROA. This table also reports the model specifications: AR (1) and AR (2) are tested for the first-order and second-order serial correlation, under null hypothesis $A R(2)$ is no serial correlation. The Hansen test over-identifications under the null hypothesis that all instruments are valid. The difference-in-Hansen test of exogeneity is under the null hypothesis that instruments used for the equations in levels are exogenous 
Table 4 Regression results of influencing role of managerial overconfidence in the relationship of corporate governance mechanisms and firm performance (TQ)

\begin{tabular}{|c|c|c|c|c|c|c|c|}
\hline \multirow[t]{2}{*}{ Variables } & \multicolumn{7}{|c|}{ Firm performance (TQ) } \\
\hline & (1) & $(2)$ & (3) & (4) & (5) & (6) & (7) \\
\hline \multirow[t]{2}{*}{ L.TQ } & $0.658^{* * *}$ & $0.658^{* * *}$ & $0.658^{* * *}$ & $0.659^{* * *}$ & $0.653^{* * *}$ & $0.661^{* * *}$ & $0.659^{* * *}$ \\
\hline & $(0.0274)$ & $(0.0275)$ & $(0.0275)$ & $(0.0277)$ & $(0.0270)$ & $(0.0275)$ & $(0.0276)$ \\
\hline \multirow[t]{2}{*}{ BIND } & 0.612 & 0.604 & 0.361 & 0.582 & 0.787 & 0.636 & 0.653 \\
\hline & $(1.425)$ & $(1.425)$ & $(2.528)$ & $(1.425)$ & $(1.415)$ & $(1.422)$ & $(1.425)$ \\
\hline \multirow[t]{2}{*}{ DUAL } & 0.0416 & 0.0401 & 0.0394 & 0.0598 & 0.0191 & 0.0440 & 0.0397 \\
\hline & $(0.125)$ & $(0.125)$ & $(0.125)$ & $(0.219)$ & $(0.125)$ & $(0.125)$ & $(0.125)$ \\
\hline \multirow[t]{2}{*}{ OWCON } & $0.0160^{* * *}$ & $0.0165^{* * *}$ & $0.0162^{* * *}$ & $0.0164^{* * *}$ & $0.0260^{* * *}$ & $0.0168^{* * *}$ & $0.0166^{* * *}$ \\
\hline & $(0.00403)$ & $(0.00405)$ & $(0.00405)$ & $(0.00406)$ & $(0.00626)$ & $(0.00409)$ & $(0.00402)$ \\
\hline \multirow[t]{2}{*}{ DF } & $-0.712^{* *}$ & $-0.709^{* *}$ & $-0.711^{* *}$ & $-0.708^{* *}$ & $-0.747^{* *}$ & $-1.062^{* *}$ & $-0.705^{* *}$ \\
\hline & $(0.325)$ & $(0.326)$ & $(0.327)$ & $(0.326)$ & $(0.325)$ & $(0.492)$ & $(0.326)$ \\
\hline \multirow[t]{2}{*}{ PMC } & $2.777^{* * *}$ & $2.775^{* * *}$ & $2.776^{* * *}$ & $2.789^{* * *}$ & $2.745^{* * *}$ & $2.778^{* * *}$ & $2.848^{* * *}$ \\
\hline & $(0.578)$ & $(0.579)$ & $(0.577)$ & $(0.579)$ & $(0.573)$ & $(0.578)$ & $(0.640)$ \\
\hline \multirow[t]{2}{*}{ MOC } & & -0.00451 & -0.0150 & 0.0147 & 0.289 & $-0.303^{* *}$ & -0.00155 \\
\hline & & $(0.0253)$ & $(0.795)$ & $(0.0619)$ & $(0.252)$ & $(0.139)$ & $(0.0282)$ \\
\hline \multirow[t]{2}{*}{ FSIZE } & $-0.169^{* * *}$ & $-0.169^{* * *}$ & $-0.169^{* * *}$ & $-0.170^{* * *}$ & $-0.174^{* * *}$ & $-0.175^{* * *}$ & $-0.169^{* * *}$ \\
\hline & $(0.0358)$ & $(0.0358)$ & $(0.0359)$ & $(0.0357)$ & $(0.0352)$ & $(0.0355)$ & $(0.0358)$ \\
\hline \multirow[t]{2}{*}{ FAGE } & $0.169^{* *}$ & $0.168^{* *}$ & $0.164^{* *}$ & $0.165^{* *}$ & $0.199^{* * *}$ & $0.174^{* *}$ & $0.166^{* *}$ \\
\hline & $(0.0680)$ & $(0.0673)$ & $(0.0638)$ & $(0.0669)$ & $(0.0619)$ & $(0.0682)$ & $(0.0676)$ \\
\hline \multirow[t]{2}{*}{ SGWTH } & 0.0482 & 0.0474 & 0.0459 & 0.0468 & 0.0411 & 0.0509 & 0.0482 \\
\hline & $(0.0630)$ & $(0.0631)$ & $(0.0636)$ & $(0.0635)$ & $(0.0632)$ & $(0.0632)$ & $(0.0631)$ \\
\hline \multirow[t]{2}{*}{ Moc*BIND } & & & $-4.624^{*}$ & & & & \\
\hline & & & $(2.396)$ & & & & \\
\hline \multirow[t]{2}{*}{ Moc*DUAL } & & & & -0.0672 & & & \\
\hline & & & & $(0.182)$ & & & \\
\hline \multirow[t]{2}{*}{ Moc*OWCON } & & & & & $-0.0156^{* * *}$ & & \\
\hline & & & & & $(0.00500)$ & & \\
\hline \multirow[t]{2}{*}{$\operatorname{Moc}^{*} \mathrm{DF}$} & & & & & & $0.735^{* *}$ & \\
\hline & & & & & & $(0.332)$ & \\
\hline \multirow[t]{2}{*}{ Moc*PMC } & & & & & & & -0.0828 \\
\hline & & & & & & & $(0.363)$ \\
\hline \multirow[t]{2}{*}{ Constant } & 0 & $3.109^{* * *}$ & 0 & $3.134^{* * *}$ & 0 & 0 & 0 \\
\hline & (0) & $(0.955)$ & (0) & $(0.961)$ & (0) & (0) & (0) \\
\hline Industry and year dummies & Yes & Yes & Yes & Yes & Yes & Yes & Yes \\
\hline Observations & 11,634 & 11,634 & 11,634 & 11,634 & 11,634 & 11,634 & 11,634 \\
\hline Number of firms & 2,492 & 2,492 & 2,492 & 2,492 & 2,492 & 2,492 & 2,492 \\
\hline AR(1) test ( $p$-value) & 0.000 & 0.000 & 0.000 & 0.000 & 0.000 & 0.000 & 0.000 \\
\hline AR(2) test ( $p$-value) & 0.334 & 0.338 & 0.348 & 0.271 & 0.305 & 0.301 & 0.323 \\
\hline Hansen test of over identification & 0.132 & 0.146 & 0.144 & 0.101 & 0.144 & 0.1658 & 0.126 \\
\hline Difference test of exogenous & 0.151 & 0.181 & 0.190 & 0.123 & 0.188 & 0.185 & 0.192 \\
\hline
\end{tabular}

${ }^{*}, * * \&^{* * *}$ represent the statistical significance at $1 \%, 5 \%$, and $10 \%$ level, respectively Notes This table reports the GMM regression results to capture the relationship of CG and firm performance, and interaction effect of MOC and CG on performance. Variables included in the model is described in Table 3, except dependent variable measured by Tobin's Q (TQ)

board in Chinese listed firm simple assigned to fulfill the institutional obligation of one-third ratio.

CEO duality has a negative significant relationship with firm performance measured by TQ $(\beta=0.103, p<0.000)$, but has no significant relationship with accounting-based firm performance (ROA). Therefore, this result supports our hypothesis 2 , which proposed there is a negative relationship between dual leadership and firm performance. 
This finding is also in line with the agency theory assumption that suggests CEO duality could reduce the board's effectiveness of its monitoring functions, leading to further agency problems and ultimately leads poor firm performance [41, 83]. This finding consistent with prior studies $[15,56]$ that indicated a negative relationship between $\mathrm{CEO}$ dual and firm performance, against to this result the studies [70] and [15] found that duality positively related to firm performance.

Hypothesis 3 is supported, which proposes there is a positive relationship between ownership concentration and firm performance. Table 3 result shows that there is a positive and significant relationship between the top ten concentrated ownership and ROA and TQ (0.00046 \& $0.06)$ at $1 \%$ and $5 \%$ significance level, respectively. These findings are consistent with agency theory, which suggests that the shareholders who hold large ownership alleviate agency costs and information problems, monitor managers effectively, consequently enhance firm performance [81]. This finding is in line with Wu and Cui [90], and Pant et al. [69]. Concentrated shareholders have a strong encouragement to watch strictly over management, making sure that management does not engage in activities that are damaging to the wealth of shareholders [80].

The result indicated in Table 3 PMC and firm performance (ROA) relationship was positive, but statistically insignificant. However, PMC has positive $(\beta=2.777)$ and significant relationships with TQ's at $1 \%$ significance level. Therefore, this result does not support hypothesis 4 , which predicts product market competition has a positive relationship with firm performance in Chinese listed firms. In this study, PMC is measured by the percentage of market concentration, and a highly concentrated product market means less competition. Though this finding shows high product market concentration positively contributed to market-based firm performance, this result is consistent with the previous study; Liu et al. [57] reported high product market competition associated with poor firm performance measured by TQ in Chinese listed firms. The study finding is against the theoretical model argument that competition in product markets is a powerful force for overcoming the agency problem between shareholders and managers, and enhances better firm performance (Scharfstein and [78]).

Regarding debt finance and firm performance relationship, the impact of debt finance was found to be negative on both firm performances as expected. Thus, this hypothesis is supported. Table 3 shows a negative relationship with both firm performance measurements (0.059 and 0.712$)$ at $1 \%$ and $5 \%$ significance level. Thus, hypothesis 5 , which predicts a negative relationship between debt financing and firm performance, has been supported. This finding is consistent with studies ([86]; Pant et al., [69]; [77, 82]) that noted that debt financing has a negative effect on firm values.

This could be explained by the fact that as debt financing increases in external loans, the size of managerial perks and free cash flows increase and corporate efficiency decrease. In another way, because the main source of debt financers is state-owned banks for Chinese listed firms, these banks are mostly governed by the government, and meanwhile, the government as the owner has multiple objectives such as social welfare and some national issues. Therefore, debt financing fails to play its governance role in Chinese listed firms.

Regarding control variables, firm age has a positive and significant relationship with both TQ and ROA. This finding supported by the notion indicates firms with long age have long history accumulate experience, and this may help them to incur better performance (Boone et al. [8]). Firm size has a significant positive relationship with firm performance ROA and negative significant relation with TQ. The positive result supported the suggestion that large firms get a higher market valuation from the markets, while the negative finding indicates large firms are more complex; they may have several agency problems and need additional monitoring, which results in higher operating costs [84]. Growth opportunity was found to be in positive and significant association with $\mathrm{ROA}$; this indicates that a firm high growth opportunity can increase its performance.

\section{Influences of managerial overconfidence in the relationship between CG measures and firm performance}

Hypothesis 2a It predicts that managerial overconfidence negatively influences the relationship of independent board and firm performance. The study findings indicate a negative significant influence of managerial overconfidence when the firm is measure by Tobin's $Q$ $(\beta=-4.624, p<0.10)$, but a negative relationship is insignificant when the firm is measured by ROA. Therefore, hypothesis $2 \mathrm{a}$ is supported when firm value is measured by TQ. This indicates that the independent directors in Chinese firms are not strong enough to monitor internal CEOs properly, due to most Chinese firms merely include the minimum number of independent directors on a board to meet the institutional requirement and that independent directors on boards are only perfunctory. Therefore, the impact of independent board on internal directors is very weak, in this situation overconfident CEO becoming more powerful than others, and they can enact their own will and avoid compromises with the external board or independent board. In another way, the 


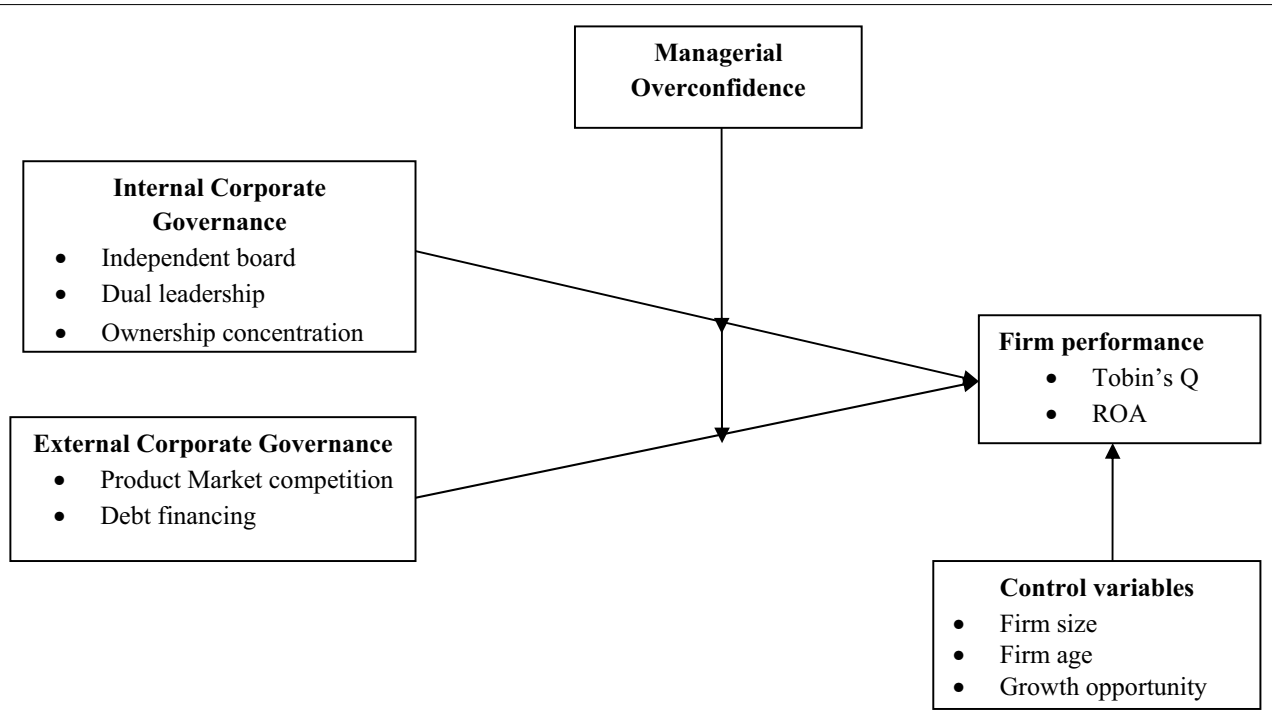

Fig. 1 Proposed research model framework

weakness of independent board monitoring ability allows CEOs overconfident that may damage firm value.

The interaction of managerial overconfidence and CEO duality has a significant negative effect on operational firm performance $(0.0202, p>0.05)$ and a negative insignificant effect on TQ. Thus, Hypothesis $2 \mathrm{~b}$ predicts that the existence of overconfident managers strengthens the negative relationships of dual leadership and firm performance has been supported. This finding indicates the negative effect of CEO duality amplified when interacting with overconfident CEOs. According to Legendre et al. [51], argument misbehaviors of chief executive officers affect the effectiveness of external directors and strengthen the internal CEO's power. When the CEOs are getting more powerful, boards will be inefficient and this situation will result in poor performance, due to high agency problems created between managers and ownerships.

Hypothesis 2c is supported It predicts the managerial overconfidence decreases the positive impact of ownership concentration on firm performance. The results of Tables 3 and 4 indicated that the interaction effect of managerial overconfidence with concentrated ownership has a negative significant impact on both ROA and TQ firm performance (0.000404 and 0.0156 , respectively). This finding is supported by the suggestion that CEO overconfidence weakens the monitoring and controlling role of concentrated shareholders. This finding is explained by the fact that when CEOs of the firm become overconfident for a certain time, the concentrated ownership controlling attention is weakened [20], owners trust the internal managers that may damage the performance of the firms in an emerging market where external market control is weak. Overconfident managers gain much more power than rational managers that they are able to use the firm to further their own interests rather than the interests of shareholders and managerial overconfidence is a behavioral biased that managers follow to meet their goals and reduce the wealth of shareholders. This situation resulted in increasing agency costs in the firm and damages the firm profitability over time.

Hypothesis 2d It predicts that managerial overconfidence moderates the relation of product market competition and firm performance. However, the result indicated there is no significant moderating role of managerial overconfidence in the relationship between product market competition and firm performance in Chinese listed firms.

Hypothesis 2e It proposed that overconfidence managers moderate the relationship of debt financing and performance in Chinese listed firm: The study finding is unobvious; it negatively influenced the relation of debt financing with accounting-based firm performance measure $(\beta=-0.059, p<0.01)$ and positively significant market base firm performance $(\beta=0.735, p<0.05)$. The negative interaction results could be explained by the fact that overconfident leads managers to have lower debt due to overestimate the profitability of investment projects and underestimate the related risks. This finding is consistent with [38] finding that overconfident CEOs have lower debt, because of overestimating the investment projects. In another perspective, the result indicated a 
positive moderating role of overconfidence managers in the relationship of debt financing and market-based firm performance. This result is also supported by the suggestion that overconfident managers have better in accessing debt rather than rational managers in the context of China because in Chinese listed firms most of the senior CEOs have a better connection with the external finance institutions and state banks to access debt, due to their political participation than rational managers.

\section{Conclusion}

The main objectives of the study were to examine the impact of basic corporate governance mechanisms on firm performance and to explore the influence of managerial overconfidence on the relationship of CGMs and firm performance using Chinese listed firms. The study incorporated different important internal and external corporate governance control mechanisms that can affect firm performance, based on different theoretical assumptions and literature. To address these objectives, many hypotheses were developed and explained by a proposing multi-theoretical approach.

The study makes several important contributions to the literature. While several kinds of research have been conducted on the relationships of corporate governance and firm performance, the study basically extends previous researches based on panel data of emerging markets. Several studies have investigated in developed economies. Thus, this study contributed to the emerging market by providing comprehensive empirical evidence to the corporate governance literature using unique characteristics of Chinese publicity listed firms covering nine years (2010-2018). The study also extends the developing stream of corporate governance and firm performance literature in emerging economies that most studies in emerging (Chinese) listed companies give less attention to the external governance mechanisms. External corporate governance mechanisms like product market competition and debt financing are limited from emerging market CG literature; therefore, this study provided comprehensive empirical evidence.

Furthermore, this study briefly indicated how managerial behavioral bias can influence the monitoring, controlling, and corporate decisions of corporate firms in Chinese listed firms. Therefore, as to the best knowledge of the researcher, no study investigated the interaction effect of managerial overconfidence and CG measures to influence firm performance. Thus, the current study provides an insight into how a managerial behavioral bias (overconfidence) influences/moderates the relationship between corporate governance mechanisms and firm performance, in an emerging market. Hence, the study will help managers and owners in which situation managerial behavior helps more for firm's value and protecting shareholders' wealth (Fig. 1).

Generally, the previous findings also support the current study's overall findings: Phua et al. [71] concluded that managerial overconfidence can significantly affect corporate activities and outcomes. Russo and Schoemaker [76] found that there is opposite relationship between overconfidence managers and quality of decision making, because overconfident behavioral bias reduces the ability to make a rational decision. Therefore, the primary conclusion of the study is that it attempts to understand the strength of the effect of corporate governance mechanisms on firm performance, and managerial behavioral bias must be taken into consideration as one of the influential moderators.

\begin{abstract}
Abbreviations
CAFC: China accounting and finance center; CEO: Chief executive officer; CG: Corporate governance; CGMs: Corporate governance mechanisms; CSMAR: China Stock Market and Accounting Research; CSRC: China Securities Regulatory Commission; GMM: Generalized method of moments; MOC: Managerial overconfidence; R\&D: Research and development; ROA: Return on asset; TQ: Tobin Q.

\section{Acknowledgements}

Not Applicable.

\section{Authors' contributions}

On behalf of the co-author, I shall bear full responsibility for the submission and I confirm that authors listed on the title page have contributed significantly to the work. Specifically, TF has written the all parts of the manuscript (introduction, literature), collected, analyzed, and interpreted the patient data regarding the impact of corporate governance on firm performance and as well as the influence of managerial behavior in the relationships corporate governance and firm value in Chinese listed firms. The author (I) read and approved the final manuscript.
\end{abstract}

Funding

The author received no financial support for the research.

Availability of data and material

I declare that all data and materials are available.

\section{Declarations}

Competing interests

I declare that there are no conflicts of interest between authors regarding the publication of this paper.

Received: 6 April 2021 Accepted: 10 August 2021

Published: 1 November 2021

\section{References}

1. Abdullah SN (2004) Board Composition, CEO duality and performance among Malaysian listed companies. Corp Gov 4:47-61

2. Aggarwal R, Erel I, Ferreira M, Matos P (2011) Does governance travel around the world? Evidence from Institutional Investors. J Financ Econ 100(1):154-181 
3. Allen F, Gale D (2000) Corporate governance and competition. In: Vives $X$ (ed) Corporate Governance: theoretical and Empirical Perspectives. Cambridge University Press, Cambridge, U.K.

4. Arellano M, Bond S (1991) Some tests of specification for panel data: Monte Carlo evidence and an application to employment equations. Rev Econ Stud 58:277-297

5. Baccar A, Ben-Mohamed E, Bouri A (2013) Managerial optimism, overconfidence and board characteristics: toward a new role of corporate governance. Aust J Basic Appl Sci 7(7):287-301

6. Ben Barka H, Legendre F (2017) Effect of the board of directors and the audit committee on firm performance: a panel data analysis. J Manage Governance 21(3):737-755

7. Ben Mahamed E, Baccat A, Bouri A (2013) Managerial optimism, overconfidence and board characteristics: towards a new role of corporate governance. Aust J Basic Appl Sci 7(7):287-301

8. Boone AL, Casares Foedld L, Karpoff JM, Raheja CG (2007) The determinants of corporate board size and composition: An empirical analysis. J Financ Econ 85(2007):66-101

9. Boyd BK (1995) CEO duality and firm performance: a contingency model. Strateg Manag J 16(4):301-312

10. Bozec R (2005) Boards of directors, market discipline and firm performance. J Bus Finance Account 32(9-10):1921-1960

11. Brown R, Sarma N (2007) CEO overconfidence, CEO dominance and corporate acquisitions. J Econ Bus 59(5):358-379

12. Capezio A, Shields J, O'Donnell M (2011) Too good to be true: board structural independence as a moderator of CEO Pay-for-Firm-performance. J Manage Stud 48(3):487-513

13. Carpenter MA, Westphal JD (2001) The impact of director appointments on board involvement in stra- tegic decision making. Acad Manag J 44:639-660

14. Chen $\mathrm{CH}$, Al-Najiar B (2012) The determinants of board size and independence: evidence from China. Int Bus Rev 21(5):831-846

15. Chen X (2019) Corporate Governance Structures, Corporate Entrepreneurship and Firm Performance. In: a Thesis Submitted in Partial Fulfillment of the Requirements of Nottingham Trent University for the Degree of Doctor of Philosophy (PhD), Nottingham Trent University

16. Chen A, Lu SH (2015). The effect of managerial overconfidence on the market timing ability and post-buy back performance of open market repurchases. North Am J Econ Finance 33:234-251

17. Cho D, Kim J (2007) Outside directors, ownership structure and firm profitability in Korea: corporate governance. Int Rev 15(2):239-250

18. Chou J, Lilian N, Valeriy S, Qinghai W (2010) Product Market Competition and Corporate Governance. Rev Dev Finance 1(2):114-130

19. Daily CM, Dalton DR, Cannella AA (2003) Corporate governance: decades of dialogue and data. Acad Manag Rev 28(3):371-382

20. Dalton DR, Hitt MA, Certo ST, Dalton CM (2007) The fundamental agency problem and its mitigation: independence, equity, and the market for corporate control. In: Brief A, Walsh J (eds) Academy of Management Annals V3. Routledge, London, UK, pp 1-64

21. Dharmastuti, and Wahyudi (2013). The Effectivity of Internal and External Corporate Governance Mechanisms Towards Corporate Performance. Research Journal of Finance and Accounting, ISSN 2222-1697, Vol.4, No.4.

22. Dong J, Gou Y (2010) Corporate governance structure, managerial discretion, and the R\&D investment in China. Int Rev Econom Finance 19(2):180-188

23. Englmaier $F(2011)$ Commitment in $R \& D$ tournaments via strategic delegation to overoptimistic managers. Manag Decis Econ 32:63-69

24. Fama EF, Jensen MC (1983) Separation of ownership and control. J Law Econ 26(2):301-325

25. Filatotchev I, Bishop K (2002) Board composition, share ownership and underpricing of UK IPO firms. Strateg Manag J 23:941-955

26. Filatotchev I, Nakajima C (2010) Internal and external corporate governance: an interface between an organization and its environment. $\mathrm{Br} J$ Manag 21:591-606

27. Fuxiu J, Stoneb GR, Sunc J, Zhang M (2011) Managerial hubris, firm expansion and firm performance: evidence from China. Soc Sci J 48:489-499

28. García-Sánchez IM (2010) The effectiveness of corporate governance: board structure and business technical efficiency in Spain. Central Eur J Oper Environ Manag 24(1):28-43
29. García-Sánchez IM, Martínez-Ferrero J (2017) Independent directors and CSR disclosures: the moderating effects of proprietary costs. Corporate Soc Responsib Res 18(3):311-339

30. Gillan SL (2006) Recent developments in corporate governance: an overview. J Corp Finan 12(3):381-402

31. Giroud X, Mueller H (2011) Corporate Governance, Product Market Competition, and Equity Prices J Finance 66(2):563-600

32. Hair JF, Black WC, Babin BJ, Anderson RE, Tatham RL (2006) Multivariate data analysis. Pearson Prentice Hall Upper Saddle River, NJ

33. Hart OD (1983) The Market Mechanism as an Incentive Scheme. Bell J Econ 14:366-382

34. Heaton JB (2002) Managerial Optimistic and Corporate Finance. Financial Management 31(2):33-45

35. Ho P-H, Huang C-W, Lin C-Y, Yen J-F (2016) CEO overconfidence and financial crisis: evidence from bank lending and leverage. J Financ Econ 120(1):194-209

36. Hribar BP, Yang H (2016) CEO Overconfidence and management forecasting. Contemp Account Res 33(1):204-227

37. Hu HW, Tam OK, Tan MGS (2009) Internal governance mechanisms and firm performance in China. Asia Pac J Manag. https://doi.org/10.1007/ s10490-009-9135-6

38. Huang W, Jiang F, Liu Z, Zhang M (2011) Agency cost, top executives' overconfidence, and investment-cash flow sensitivity-Evidence from listed companies in China. Pac Basin Financ J 19(3):261-277

39. Ibrahim H, Samad FA (2012) Corporate governance mechanisms and performance of public-listed family-ownership in Malaysia. Int J Econom Finance 3(1):105-118

40. Jensen MC (1986) Agency costs of free cash flow, corporate finance, and takeovers. Am Econ Rev 76(2):323-329

41. Jensen MC (1993) The Modern Industrial Revolution exit and the failure of internal control systems. J Financ 48(3):831-880

42. Jensen MC, Meckling WH (1976) "Theory of the firm: managerial behavior, agency costs and ownership structure. J Finan Econom 3(4):305-360

43. Keasey K, Wright M (1993) Issues in corporate accountability and governance: an editorial. Account Bus Res 23:291-303

44. Khajavi S, Dehghani G (2016) Board Characteristics and Managerial Overconfidence in an Emerging Market: International Journal of Economics and Financial. Issues 6(2):529-537

45. Khurana R (2002) Searching for a corporate savior: The irrational quest for charismatic CEOs. Princeton University Press, Princeton, NJ.

46. Kim HA, Choi SU, Choi W (2019) Managerial overconfidence and firm profitability, Asia-Pacific. J Account Econ. https://doi.org/10.1080/16081 625.2019 .1673190

47. Kim EH, Lu Y (2011) CEO ownership, external governance, and risktaking. $J$ Financ Econ 102(2):272-292

48. Koke J, Renneboog L (2005) Do corporate control and product market competition lead to stronger productivity? Evidence from marketoriented and block holder-based governance regime. J Law Econom 48(2):475-516

49. Kumar M, Sheeba K (2018) Board characteristics and firm value for Indian companies. J Indian Bus Res 10(1):2-32

50. Kumar P, Zattoni A (2018) Corporate governance, firm performance, and managerial incentives: corporate governance. Int Rev 26(4):236-237

51. Legendre F, Ben-Barka H (2016) Effect of the board of directors and the audit committee on firm performance: a panel data analysis; J Manag Gov 21:737-755

52. Li K, Lu L, Mittoo UR, Zhang Z (2015) Board independence, ownership concentration and corporate performance-Chinese evidence. Int Rev Financ Anal 41:162-175

53. Liang Q, Ling L, Tang J, Zeng H, Zhuang M (2019) Managerial overconfidence, firm transparency, and stock price crash risk Evidence from an emerging market. China Finance Rev Int 10(3):271-276

54. Lina C, MabDongwei YS (2009) Corporate governance and firm efficiency: evidence from china's publicly listed firms: manage. Decis Econ 30:193-209

55. Liu N, Chen WH (2017) Executives' overconfidence, political connection and acquisition premium of enterprises. J Serv Sci Manag 10:260-279

56. Liu Y, Miletkov MK, Wei Z, Yang T (2015) Board independence and firm performance in China. J Corporate Finance 30(2):223-244 
57. Liu L, Qu W, Haman J (2018) Product market competition, state-ownership, corporate governance and firm performance. Asian Rev Account 26(1):62-83

58. Liu Q, Tang J, Tian GG (2013) Does political capital create value in the IPO market? Evidence from China. J Corp Finan 23:395-413

59. Lynall MD, Goden BR, Hillman AJ (2003) Board composition from adolescence to maturity: a multitheoretic view. Acad Manag Rev 28:416-431

60. Mahdi O, Mahdi M, Mohammad-Ali BV (2017) Corporate governance, productmarket competition, and firm performance: evidence from Iran. Humanomics: Int J Syst Ethics 33(1)38-55

61. Malmendier U, Geoffrey T (2005). CEO Overconfidence and Corporate Investment. LX(6)

62. Marnet O (2004) Behavioral aspects of corporate governance. Adv Financ Econ 9:265-285

63. McDonald K, Westphal JD (2008) Demographic diversity in the boardroom: mediators of the board diversity-firm performance relationship. J Manage Stud 46:5

64. Moradi M, Bagherpour Velashani MA, Omidfar M (2017) Corporate governance, product market competition and firm performance: evidence from Iran. Humanomics 33(1):38-55

65. Nguyen TTM, Evans E, Lu M (2017) Independent directors, ownership concentration and firm performance in listed companies: evidence from Vietnam. Pac Account Rev 29(2):204-226

66. Nguyen T, Locke S, Reddy K (2014) A dynamic estimation of governance structures and financial performance for Singaporean companies. Econ Model 40(C):1-11

67. OECD (2004). Principle of Corporate governance; edited 2004, Retrieved from, http://www.oecd.org/corporate/ca/corporategovernanceprinci ples/31557724.pdf

68. Oliver B (2005) The impact of management confidence on capital structure. Corp Finan Capit Struct Payout Policies eJ. https://doi.org/10.2139/ ssrn.791924

69. Pant M, Pattanayak M (2010) Corporate governance, competition and firm performance. J Emerg Market Finance 9(3):347-381

70. Peng MW, Zhang S, Li X (2007) CEO duality and firm performance during china's institutional transitions. Manag Organ Rev 3(2):205-225

71. Phua K, Mandy T, Wei C (2018) Are overconfident CEOs better leaders? Evidence from stakeholder commitments. J Financ Econ 127:519-459

72. Report H (2003) Review of the role and effectiveness of non-executive directors. The Department of Trade and Industry, London

73. Rihab BA, Lotfi BJ (2016) Managerial overconfidence and debt decisions. J Modern Account Audit 12(4):225-241

74. Roll R (1986) The hubris hypothesis of corporate takeovers. J Bus 59:197-216

75. Roodman, D (2006). How to do xtabond2: An introduction to 'difference' and 'system' GMM in Stata, Working paper no. 103, Center for Global Development.

76. Russo JE, Schoemaker PJH (1992) Managing overconfidence. Sloan Manag Rev 33:7-17

77. Sami H, Wang J, Zhou H (2011) Corporate governance and operating performance of Chinese listed firms. J Int Account Audit Tax 20:106-114

78. Schmidt KM (1997) Managerial incentives and product market competition. The Revies of economic studies 64(2):191-213
79. Shao L (2019) Dynamic study of corporate governance structure and firm performance in China: evidence from 2001-2015. Chin Manag Stud 13(2):299-317

80. Shleifer A, Vishny R (1986) Large SHAREHOLDERS AND CORPORATE Control. J Polit Econ 3:461-488

81. Shleifer A, Vishny RW (1997) A survey of corporate governance. J Financ 52(2):737-783

82. Tian L, Estin S (2007) Debt financing, soft budget constraints, and government Ownership Evidence from China. Econ Transit 15(3):461-481

83. Tian JJ, Lau CM (2001) Board composition, leadership structure and performance in Chinese shareholding companies. Asia Pacific Journal of Management 18(2):245-263

84. Ullah, Subhan (2015). The Impact of Internal Corporate Governance Mechanisms on the Performance of Firms: Evidence from the UK and Germany. PhD thesis The Open University.

85. Uribe-Bohorquez MV, Martínez-Ferrero J, García-Sánchez IM (2018) Board independence and firm performance: The moderating effect of institutional context. J Bus Res 88:28-43

86. Vicente-Lorente JD (2001) Specificity and opacity as resource-based determinants of capital structure: evidence for Spanish manufacturing firms. Strateg Manag J 22(2):157-177

87. de Villiers C, Dimes R (2020) Determinants, mechanisms and consequences of corporate governance reporting: a research framework. J Manag Gov 25:7-26

88. Wang Y, Fan W (2014) R\&D reporting methods and firm value: evidence from China. Chin Manag Stud 8(3):375-396

89. Wintoki MB, Linck JS, Netter JM (2012) Endogeneity and the dynamics of internal corporate governance. J Financ Econ 105(3):581-606

90. Wu S, Cui H (2002) Consequences of the concentrated ownership structure in Mainland China_Evidence of Year 2000. Working paper, City University of Hong Kong

91. Yasser QR, Mamun AA, Rodrigs M (2017) Impact of board structure on firm performance: evidence from an emerging economy. J Asia Bus Stud 11(2):210-228

92. Yu J, Wen S (2013) Intellectual capital, corporate governance and firm performance. Inf Manage Bus Rev AMH Int 5(10):482-491

93. Zahra SA, Pearce JA (1989) Boards of directors and corporate financia performance: a review and integrative model. J Manag 15:291-334

94. Zavertiaeva MA, López-Iturriaga JF, Kuminova V (2018) Better innovators or more innovators? Managerial overconfidence and corporate R\&D: Manage Decis Econ 39(4):447-461

95. Zhang Q, Lilin C, Feng T (2014) Mediation or moderation? The Role of R\&D investment in the relationship between corporate governance and firm performance: empirical evidence from the Chinese IT industry. Corporate Governance An Int Rev 22(6):501-517

96. Zhang W, Wang K, Li L, Chen Y, Wang X (2018) The impact of firms' mergers and acquisitions on their performance in emerging economies. Technol Forecast Soc Chang 135(2):208-216

\section{Publisher's Note}

Springer Nature remains neutral with regard to jurisdictional claims in published maps and institutional affiliations. 